\title{
LABOUR MIGRATION AND STRUCTURAL HETEROGENEITY IN WEST AFRICA
}

by Alfred Schmidt

\section{Introductory Remarks}

This paper ${ }^{1}$ undertakes a critical analysis of some views on modern migration in West Africa which have been developed on the basis of dualistic theories of development. Labour migration is interpreted, similar to Amin (1974) ${ }^{2}$, as a mechanism which connects different structural elements of periphery capitalist societies. In order to avoid misunderstandings it seems necessary to clarify a few concepts used later. The concept of mode of production does not limit itself to the technical and organisational side of material production or to "economic" phenomena. It denotes a total structure including not only economic but also other phenomena which, considered alone, appear as "politics" or "ideology". Used as an abstract concept, social formation signifies a combination of elements belonging to different modes of production into one structure. One mode of production can thereby be interpreted as dominant in so far as it determines the linkage between different elements and their collaboration. In the case of the socalled developing societies the dominance of the capitalist mode of production is characterized by its instability ${ }^{3}$. The relative autonomy of non-capitalist elements prevents therefore a tendency towards homogeneity of the total structure. Such elements are not simply traditional relics doomed for decline. They constitute an inherent component of the structure of periphery capitalist social formations.

In spite of this implicit claim to a total analysis the presentation in this paper is very much partial. Economic phenomena are given the central attention whereas social and political phenomena get merely an occasional look. Moreover, the empirical studies this paper is based upon limit themselves to a few countries in West Africa, especially Ghana, Ivory Coast, Senegal and Upper Volta. Therefore attention should be drawn to the fact that the problems analysed in a specific regional context cannot be necessarily transferred to other regions of the periphery ${ }^{4}$.

\section{The economic structure of West African countries}

Societies at the periphery of the capitalist world distinguish themselves from the metropoles with regard to their economic structure. A conspicuous feature of the peripheral economies is their incompleteness and incoherence. Since most of the capital goods used in modern industries ${ }^{5}$ are not produced by themselves, the

\footnotetext{
$1 \mathrm{It}$ is the revised version of a paper presented at the conference "Underdevelopment and Subsistence Reproduction", held at the Zentrum für Interdisziplinäre Forschung, University of Bielefeld, May $26-28,1977$.

2 Cf. also Amselle, 1976, and Habermeier, 1977.

3 Cf. also Schmidt, 1976, pp. $108-112$.

4 Cf. Amin, 1974, pp. 68/9, 78-84; Arrighi, 1970, p. 222; Berg, 1961, p. 490; Lloyd, 1972, p. 92.

5 In this context the attribute "modern" indicates that the application of techniques of production is comparable to that in the metropoles.
} 
export sector serves as a substitute for a domestic production of capital goods. Modern industries which produce substitutes for consumption goods imported earlier possess only weak linkages with the remaining sectors. Their growth depends on the export sector where the final demand for their products, the surplus available for investment and the foreign exchange necessary for the import of raw materials, intermediate goods and machines mainly originate. The remaining modern activities in urban areas serve either the state's administration and infrastructural services or the conduct of foreign trade. Besides these modern sectors there exist extensive "traditional" sectors, both in urban and rural areas, which are however of marginal significance for the dynamic of reproduction. In rural areas they constitute subsistence economies which supply partly migratory labour for the modern sectors. The migrants in urban areas, who cannot be absorbed in the modern sector, make an opening for their existence through offering multifarious types of services. An important connecting link for the distribution of goods among all these sectors are the numerous small traders who cannot replace, however, the missing relationships among the production structures of various sectors. These sectors, characterized by different modes of production, are, however, interdependent in so far as their development is determined by the production for exports and the partial integration brought about thereby into the world market. Their structural heterogeneity and inadequate integration prohibit that the growth impulses could be transmitted from one sector to the other and thereby gain strength ${ }^{6}$.

This general characterization of peripheral economies applies also to West Africa? Agricultural production for exports emerged as a leading sector for economic growth already in the 19th century. Individual countries specialized in various agricultural products, such as groundnuts and cocoa, according to their given geographical conditions. Even after independence these products constitute twothird of West African exports concentrating on one ar a few products. They are almost entirely grown by African farmers, partly with the help of employed labour. The most important field of investment for foreign capital is the extractive sector, especially minerals and timber meant for exports. The Africans in this sector participated until recently only as wage labour. With a very few exceptions there existed before the second world war neither industries for consumption and capital goods nor for processing raw materials for exports. The development of material and cultural infrastructure by colonial administrations served the purpose to secure political dominance and production for exports. Those areas were given a special attention whose development was attractive for foreign capital.

Whereas the export-oriented economic sectors have made considerable growth strides since the beginning of this century, the expansion and commercialisation of indigenous food production lags far behind the increased demand resulting from population increase and urbanization. The governments have formulated development plans after independence to push forward the so far neglected industries and to diversify agriculture, but the success is confined mainly to the field of infrastructure. In addition to the provision of infrastructure the governments are

6 Cf. Senghaas, 1975 , pp. $261-268$.

7 Cf., e. g. Amin, 1974, pp. 93-110; Arrighi, 1970; Hopkins, 1973, pp. 167-292; Lloyd, 1972, pp. 68-78. 
trying to attract foreign investments through financial incentives like protection duties, tax reliefs and financial participation. As a result, import-substitution industries have emerged side by side of new investment in the extractive sector. The result has been a strong tendency towards urban agglomerations without creating any connecting links neither between sectors and regions within individual economies nor any advance in the field of interregional division of labour. On the contrary, the protective walls everywhere have facilitated the emergence of identical industries which are too large for the internal market because of their foreign technology and orientation towards the demand structure characterized by existing inequalities in the distribution of income.

Such structural mutuality is combined with differences among African countries $^{8}$. The limits of growth, which is carried by agricultural production for exports and import-substitution in the field of light-industry, are clearly shown by Senegal and Ghana. The outward-oriented development of these countries began already before the first world war as compared to that of Ivory Coast - the economic wonderland of today - whose capitalist penetration really started first after the second world war. Finally, the big differences between the development levels of these coastal lands and the land-locked countries like Mali and Upper Volta cannot be overlooked as well. They were practically excluded from a development of agricultural production for exports during the colonial period. Above all, as exporters of labour force they participate in the export-oriented development of their neighbouring countries.

\section{The making of a migrating labour force during the colonial period}

A major section of the African wage-earners during the colonial period is characterized by high rates of fluctuations, unsteady labour supply and low qualification. These "semiproletarian" workers "are setting, so to speak, one foot in the industrial system while the other remains in rural society" 9 . This puts a serious obstacle to the development of modern industry. It does not simply mean an innate inefficiency of the African labour. These characteristics reflect much more the manner in which the labour force was mobilized for modern activities during the colonial period. Most important determinants of this development regarding the wage-earners are explained in the following subsections.

\subsection{The expansion of agrarian export production}

The taking up of agricultural production for exports begins in West Africa around the middle of 19 th century, just before the colonial period ${ }^{10}$. Partly, its extension presupposes a destruction of traditional modes of production. Partly, it proceeds in the first instance from unaltered relations of production. That shows itself through the different development of peanut cultivation in Senegal and cocoa in Ghana ${ }^{11}$.

8 Cf., e. g. Amin, 1971; IMF, 1973; IMF, 1975; World Bank Atlas, 1975, p. 14

9 Little, 1974, p. 34.

10 Cf. Hopkins, 1973 , pp. $125-135$.

11 Cf. Amin, 1971, pp. 34, 70/1, 87; Lloyd, 1972, pp. 96-99; for Senegal: Amin, 1971, pp. 25-29, 33/4; N'Doye, 1974; for Ghana: Adomako-Sarfoh, 1974, pp. 142-147; Hill, 1963; Hopkins, 1973, pp. 216-218, $232-235,238 / 4$. 
The extension of peanut cultivation in Senegal, advancing from west to east, is linked with fundamental changes in the relations of production. This is reflected primarily in the fact that ownership relations emerge with regard to land, and the land ownership goes increasingly into private hands. With labour and production relations getting increasingly individual the prevailing collective system is undermined. Social relations at the village level regulated so far on a non-economic basis are commercialized. In expanding production the labour force produces bottlenecks, to begin with. That is overcome through the seasonal labour especially from Mali, which is related to the institution of paid labour. The application of improved working implements and fertilizers becomes necessary first in the 1950's. The concentration of land ownership proceeds with the modernization of production, to which corresponds a release of labour force due to higher per capita production. The migration flow of new labour force from Mali exhausts therewith.

The traditional system of land ownership in southern Ghana, which the British colonial administration tries to fix up legally, remains apparently valid. However, the regulations like prohibition of outright sale of land belonging to the tribe were evaded. Thus an accumulation process proceeds along the spatial expansion through which an individual farmer succeeds in acquiring a considerable property of scattered cocoa farms. A part of the cocoa farmers distinguishes itself as capitalist farmers also through the employment of labour paid in cash or kind. The dependent employment extends from tenancy system - in which the land owner gets a fixed share of the crops - to the daily wages. The additionally required labour force is provided by the migratory labour from the northern hinterland and the neighbouring states. The hidden proletarianizing which accompanies the accumulation process in the production of agricultural exports does not affect primarily the indigenous population but the immigrant labour from the north and the east.

The final result in both cases is similar: the agricultural production is not only subjected indirectly to the capitalist mode of production, viz. through the sphere of circulation and the integration in the world market. Capitalist production relations permeate also directly the labour process of the sectors concerned.

\subsection{The connection between subsistence economies and modern activities}

Working as a wage-earner implies a separation of the direct producers from the means of production. This problem becomes evident during the first decades of the colonial period when the colonial powers think to have taped considerable labour force reserves in the West African hinterland. Because of the communal land ownership there exists no landless "proletariat" which could be simply transplanted in the modern sectors ${ }^{12}$. Positive incentives such as the supply of imported consumer goods purchasable with money do not completely achieve their purpose. Poll taxes in terms of money offer effective means in areas separated from those producing agricultural exports. "Traditional rulers" who are transformed or established ad hoc as agents for colonial administration were drawn into the recruitment of labourers for "public works". Such compulsory labour

\footnotetext{
12 Cf. Arrighi, 1970, p. 234; Little, 1974, pp. 106/7. It may also apply to the former "house slaves" who were freed by intervention of colonial administrations since the middle of 19th century. Cf. Hopkins, 1973, pp. 225-229.
} 
was employed even in the private economic sector ${ }^{13}$. Nevertheless, migratory labourers can seek favourable working conditions and wage-rates if they cannot avoid the necessity of wage labour at all. For example, many residents of Upper Volta avoid the recruitment for employment in Ivory Coast through the emigration to the neighbouring Ghana. The demand of the cocoa farmers for labour force there affects the "concerted action" of private and state employers in the nonagricultural sector who try to dictate the working conditions and wagerates $^{14}$. Compulsory measures and other interventions of colonial administrations possess, of course, only the function to initiate the process of labour migration. Then the concerned population itself keeps it going. Some economists take a system of seasonal labour migration between the subsistence economies and agricultural export sectors as an efficient reallocation of labour as a factor of production and as an optimum adjustment of production to the "natural" conditions $s^{15}$. Young men who do traditionally the hardest work in particular participate in the seasonal migration. The village communities can lose in this way the manpower for community work. Whether the consumption possibilities of the remaining population renain preserved or impaired depends on the degree of solidarity within the family units and the village communities, since that would influence the length and timing of labour migration. The traditional subsistence economies become in any case dependent on the migrant wage-earners, even when the food production does not decline. On the one hand, money income and the commodities brought with replace the non-agricultural goods which the migrants have produced formerly during the slack period. On the other hand, work done on reciprocal basis within the communities is regulated on a monetary basis and the social relations are commercialised ${ }^{16}$. Since the returning migrants bring new ideas, production techniques and instruments, the labour migration appears in the long run as a medium of social change in the countryside. The transfer of commodities and money, however, and the new attitudes which migrants bring with them from the capitalist environment, are not adequate in themselves to initiate a process of structural changes towards "modernization" of the subsistence economies. If consumption patterns and value systems which induce further migration are transferred, but not innovations for production, then the result of labour migration is rather a further deepening of unequal development between the partial regions of West Africa and a further consolidation of structural heterogeneity ${ }^{17}$. Under the existing conditions in West Africa this result can also be deduced exactly from orthodox models of regional growth which usually serve to underpin the thesis of integration between traditional and modern sectors ${ }^{18}$.

\footnotetext{
13 Cf., e. g. Crowder, 1968, pp. 184-187, 208/9, 337-339; Habermeier, 1977, pp. 246-248, 273-277, 292-307; Little, 1974, pp. 8/9; Skinner, 1965.

14 Cf. Skinner, 1965. For monopolistic as well as competitive elements on the demand side of labour markets cf. Crowder, 1968, pp. 304/5 and Berg, 1961, p. 489; Hopkins, 1973, p. 222.

15 Cf. Berg, 1965, p. 164. He states that West African labour markets are "close approximations to "perfect markets", since "the migrant labor force is homogeneously unskilled and transferable between employments" (p. 162). This view overlooks the occupational specialization of ethnic groups, and the resulting segmentation of the labour market. For Ghana cf. Hill, 1970, pp. 36-56.

16 Cf. Habermeier, 1977 , pp. $334-372$.

17 For different views among economists and social scientists on the allocative efficiency, and the diffusoin of modernizing impulses by lavour migration cf., e.g. Amin, 1974, pp. 68/9; Arrighi, 1970, p. 254; Hart, 1974, pp. 325, 330; Kuper, 1965, pp. 13/9; Little, 1974, pp. 103/4; Lloyd, 1972, pp. 94/5; Skinner, 1965, pp. $70-72$.

18 Cf. Siebert, 1969, especially pp. 151/2; for a contrary view cf. Berg, 1965, pp. 172, 176/7. Empirical data which indicate growing interregional and intersectoral differences are found in Amin, 1971, pp. 95, 97; cf. also Darkoh, 1975, pp. 112/3; Little, 1974, p. 41.
} 


\subsection{The consequences of migration for wage labour in non-agrarian activities}

The interventions of colonial administrations which render the people of subsistence economies as migratory labour benefit the agricultural production for exports only secondarily. The dominant problem of recruiting the labour force during the colonial period lies in directing it into the sectors predetermined by Europeans and to discipline this labour force according to the organization and technical requirements of the capitalist process of production. Compulsory measures have shown to be less efficient to overcome the attractiveness of the traditional land ownership system. The short-term labour migration does not thus limit itself to migration movements between subsistence economies and zones of agricultural exports, but also extends to the non-agricultural activities. The employers take into account the basis for remuneration consciously which the immigrant labour gets in village communities. This restrictive wage policy is based on the assumption that the immigrants would work more through lower wages as "target workers" because they would achieve at every cost their income goals ${ }^{19}$. That hinders the proletarianizing process because the labour migrants are only partially engaged in the modern sector. The combination of capitalist structures with non-capitalist elements makes an economic system viable where the paid wages alone would not be sufficient for the reproduction of the labour force, because certain important functions in this system, such as rearing and maintenance of labour in sickness and old age, can be shoven off to the subsistence economies ${ }^{20}$. The problems related to this connection of heterogeneous structural elements through the labour migration are already evident during the colonial period. The demand for African technical hands and qualified workers can not be met inspite of the almost missing industrialization. For this situation a lack of training facilities is not much responsible Low wages and bad working conditions appear to be more decisive. They do not offer any incentive for the qualification of African labour ${ }^{21}$. Another important result of labour migration is the weak position of the dependent labourers in the labour market. It appears in so far as paradoxical that the related conditions - as usually quoted in capitalist societies, i. e. the "double freedom" of wage-earners do not exist in general in West Africa at the beginning of colonial period.

The administrations undertake the role of price leadership from the demand side of the labour market, since they are themselves the most important individual employers. Equipped with the compulsion means of state power they can create conditions under which the labour market is glutted with casual labour and where trade unions are very difficult to organize even without legal prevention. The weakness of organized presentation of interests of the workers relates significantly to the integration of migrant labour in the non-capitalist structures. Voluntary

19 Cf. Lloyd, 1972, pp. 121, 123; Roper, 1958, p. 39. For a criticism of the assumed 'backward sloping labour supply curve' cf. Berg, 1961 .

$20 \mathrm{Cf}$. Arrighi, 1970, pp. 235/6. Meillassoux, 1972 (an earlier and condensed version of his Femmes, gremiers et capitaux, part II) introduces the concept of "labour rent" for the subsidy of capitalist production by "self sustaining communities". This may be interpreted as a 'rent', but more in the sense of neoclassical economics, not in the sense of Marx (1968, pp. 798-802). In neoclassical terms, this 'superexploitation' results from monopolistic elements on the demand (eniployers') side of the labour market. They depress wages below the long-run competitive equilibrium level where normal exploitation of capitalist workers is assumed to start. One may formulate, by analogy with Meillassoux, the supply of labour-power as a problem of its production (and reproduction): the actual wage per labourer covers only the (short-run 'variable') costs of sustaining the labour-power spent by the individual labourer, but not the ('total average') costs necessary to maintain and reproduce capitalist workers as a group. This difference is what Meillassoux calls "labour rent".

21 Cf. also Hopkins, 1973, pp. 229-231; Roper, 1958. 
associations outside the traditional kinship relations can be partially traced back in West Africa through hundreds of years of tradition. However, these are as much inadequate to regulate new kinds of conflict as the heads of clans who mediate in the customary disputes. The majority of migrant labour is especially obstructive against joint action outside the traditional paths. One's own tribal headman is trusted more to represent the interests than a trade unionist stranger. Tendencies for trade union organization are therefore available especially in those places where a regularly employed labour force dominates, as in case of public service. In the remaining spheres such as mining the trade union members are found only among the regular employed ${ }^{22}$.

The colonial administrations believe still to overcome the inefficiency of their recruitment of labour force through compulsory measures or through employing non-Africans. The potential of conflict, which the structures of periphery capitalism contain, remains largely latent. The contradictory character of this structure becomes apparent first after formal decolonization.

\section{Rural-urban migration and urban unemployment}

The accelerated urbanization in West Africa, which concentrates after the second world war on a few big cities with more than 100000 inhabitants, is not so much due to a natural increase in population but is a result of rural-urban migration. Big cities, and not the rural export-zones, are the major attractors of migrating labour, who come not only from economically backward areas but also from agricultural exporting zones ${ }^{23}$. The impetus has come from the increasing importance of these cities as political and cultural centres of independent states and as industrial centres of import substitution following decolonization. However, the increase in jobs for wage and salary earners does not keep pace with the increase in active population in urban centres. This is reflected in the important unemployment figures during the last two decades, which certainly represent only a part of the urban unemployment ${ }^{24}$. Institutionally fixed wages in modern urban sectors apparently higher than warranted by the relative scarcities of capital and labour are cited as a reason for the rural-urban migration and the resultant employment problems. If the differences in real income between rural and urban areas are considerable, it pays for a migrant to undertake the risk of a temporary unemployment in the town. On the other side, higher wage rates are held responsible for the choice of capital intensive technologies, with the result that investments carry low employment effects in spite of higher increases in production ${ }^{25}$.

The hypothesis of behaviour based on these considerations regarding rural-urban migration has been empirically tested for Ghana. In spite of dissatisfying data and considerably defective sources, these tests do not support the hypothesis of

22 Cf. Arrighi, 1970, pp. 238/9; Little, 1974, pp. 89/90; 92/3; Lloyd, 1972, pp. 104, 193-203; Roper, 1958.

23 Empirical data on urbanization are found in Amin, 1974, p. 79; Frank, 1968, p. 253; Little, 1974 , pp. 109/10; Lloyd, 1972, pp. 110-113.

24 On unemployment cf. Amin, 1971, pp. 46/7 Frank, 1968, pp. 253-255; IMF, 1973, pp. 247, 553; IMF, 1975, p. 123; Joshi et al., 1975, pp. 289-291; Todaro, 1973, p. 95

25 In recent years the most «sophisticated" and influential model of this kind was developed by Todaro, 1969 and 1973. Cf. also Frank, 1968; Reynolds, 1969. For critical views on these models cf., e. g. Godfrey, 1973, p. 75; Hart, 1974, p. 333; Jolly et. al, 1973, pp. 21/2, and the most vigorous attack by Amin, 1974, especially pp. 90-93, 107/8. 
behaviour. They point out especially to the low efficacy of restrictive wage policy which has been persued in Ghana since 196026. Not only empirical studies but also theoretical considerations speak against economic hypotheses of migration as explanations for urban unemployment, with wage rate as a strategic variable. The decisive influence of wage rates in the choice of techniques depends upon restrictive premises, especially the possibility of substitution between labour and capital as factors of production, not only with regard to investment decisions before taking up production, but also during production. Further, it is overlooked that the capital goods produced and available in the world market are meant for the needs of developed industrialized countries and that these prefer capital intensive rather than labour intensive methods of production. The choice of techniques is therefore subject to a bias because labour and capital intensive technologies differentiate qualitatively in the applied means of production. In case of labour intensive methods of production technically outdated machines must be used $^{27}$. Finally, the qualitative composition of the African labour supply must be taken into account while judging the relative scarcity of capital and labour. Skilled workers present a decisive bottleneck. Semiskilled workers can be much easily trained for capital intensive processes whereas a few highly qualified employees can be initially imported by the foreign firms and later replaced by "elite" Africans ${ }^{28}$. The low qualification of African labour, which goes back to the recruitment and wage policy during the colonial period, shows thus as one reason for the actual employment problems in modern urban centres.

The apparently high wage rates are also related to this colonial "heritage" 29 . As a result of the minimum wage legislation after independence the nominal wages are rising rapidly. This legislation takes the fact into account that the wage labour in modern sectors cannot be subsidized any more by the non-capitalist subsistence economies. Migration to big cities is primarily a long-term phenomenon for which seasonal migration or other short-term stay in the cities simply precede. Migrants do not only consist of single workers but also their near families. Through the dissolution of rural subsistence economies and decreasing links of the absent migrants with their villages, the kinship bonds also lose their role as a substitute for social insurance. The wages must now be raised to a level that the reproduction of capitalist workers as a group is secured. Of course, the development of money wages and the cost of living strongly goes asunder. Only the wages of a small minority of qualified and well organized workers lie considerably above the subsistence level.

The employment problem cannot, of course, be traced back alone due to the predominance of capital intensive techniques applied in industrialization through import-substitution. An analysis of the composition of wage and salary earners reveals that the major share goes to trade and service activities, construction, transport and small handicrafts. There is a meagre scope for further labour

26 Cf. Godfrey, 1973, Knight, 1972.

27 Cf. Arrighi, 1970, pp. 243-251; Stewart/Streeten, 1971; for a less pessimistic view on the growth dilemma of output vs. employment Ewusi, 1977. Moreover, the choice of capital-intensive techniques is influenced by state incentives for foreign direct investments which relatively cheapen capital as a factor of production.

28 Cf. Arrighi, 1970, pp. 228/9; Darkoh, 1975, p. 115; IMF, 1973, p. 261; Joshi et. al., 1975, p. 292.

29 For empirical evidence and different views on the rising wage level after independence cf. Amin 1971 pp. 48/9; Arrighi, 1970, pp. 231/2; DAMACHI, 1974, pp. 57/8; Frank, 1968, pp. 263-265; Hart, 1971, p. 32; Hopkins, 1973, pp. 273/4; IMF, 1973, pp. 550-553, 707-711; IMF, 1975, pp. 118-121; Jeffries, 1975, pp. 61-63; Knight, 1972, pp. 205/6; Lloyd, 1972, pp. 122/3, 206. See also above note 20. 
intensive technologies within the given economic structure ${ }^{30}$. In view of the financial crisis of the state whose expenditure is almost absorbed by wages and salaries, the expansion of employment opportunities in the public sector offers no scope as a solution ${ }^{31}$. This problem explains the high importance which is assumed by the "informal" urban sector in recent studies. The possibilities of a relief from temporary unemployment offered by this sector seem plausible when we consider that in spite of considerable unemployment a regular influx of labour into the urban areas continues further. Moreover, these sources of income seem even to offer incentives for migration ${ }^{32}$.

Not a single isolated factor such as rural-urban migration can be held responsible for urban unemployment. Equally, the manipulation of a single strategic variable such as wage rate cannot be taken as an adequate solution. This problem is much more to be seen from the background of structures from which originate "outward looking" models of development ${ }^{33}$.

\section{Socio-political consequences of structural heterogeneity}

Economic analyses cannot elucidate what effects labour migration has on noneconomic aspects of social integration. If one is not satisfied to see considerable horizontal mobility ${ }^{34}$ as an indice for modernization, its influence on the structure and behaviour of population must be analysed.

The stratification of West African societies exhibits certain features which are typical in capitalist societies. The deciding criterion for a classification of "elites" and "masses" in urban population are the differences in income which are reflected in the different levels of consumption and ways of living. However, a differentiation between the "old" and the "new elite" shows that the stratification scheme relates to rather amorphous categories. This distinction is based on quite different, modern and traditional value systems which are not even sharply demarcated and very often overlap ${ }^{35}$. In spite of its inadequacy this stratification scheme is justified by the supposition that the scheme of a capitalist class society for West Africa is much less relevant. Classes could not be defined with ownership of means of production because most of the "elites" are themselves employees and communal land tenure systems predominate ${ }^{36}$. Considering not so much the ownership but the power of disposition over means of production and the distribution and utilization of products, the following polarization appears: On the one side are such groups which as owners or employees direct the production and circulation processes, carrying weight in the economy. On the other side exist

\footnotetext{
30 For this solution of the employment problem cf., e. g. Joshi et. al., 1975, p. 302. Empirical data on the structure of employment are found in Amin, 1971, pp. 63, 71; Ewusi, 1977, pp. 19-26; Frank, 1968, pp. 255, 257; IMF, 1973, p p. 260, 553; Knight, 1972, p. 202.

31 Stewart/Streeten call this the "Nkrumah solution of introducing the modern factories and "employing" the additional. . . workers in some minor and completely useless capacity" (1971, p. 150). Cf. also Damachi, 1974, pp. 68/9, 92/3; Ewusi, 1977, pp. 14/5; Frank, 1968, p. 254.

32 Cf. Frank, 1968, pp. 251/2, 255; Hart, 1974; Joshi et. al., 1975; Le Brun/Gerry, 1975; Reynolds, 1969, pp. 91, 94, 96/7; Todaro, 1969, p. 139.

33 Cf., e. g. Amin, 1974, p. 120; Arrighi, 1970, pp. 240, 242; Jolly et. al., 1973, pp. 18-21; Senghaas, 1975. Against the lowering of wages as a panacea can be argued that it excludes overcoming the "narrowness of the internal market" which is conditioned by the existing structure of income distribution.

34 Cf. Amin, 1974, pp. 72-79.

35 Cf. Joshi et. al., 1975, p. 292; Little, 1974, pp. 41-47, 52/3; Lloyd, 1972, pp. 109, 126-133, 150-152. For a critical evaluation of this stratification scheme cf. Arrighi, 1970, p. 262, n. 52.

36 Cf. Lloyd, 1972, p. 315.
} 
workers, peasants, small traders and artisans as well as marginalized groups of unand underemployed ${ }^{37}$.

So far contradictions have been pointed out which are inherent in the structure of periphery capitalism. In order that these latent conflicts become open and manifest, political organizations must be built which could articulate politically the class interests against the ruling "elites". "The consciousness of the conflicting interests may be reduced through the acceptance of ideologies stressing unity or through the cross-cutting of other divisions within society $-\ldots$, especially, of ethnic divisions which, in stressing primordial loyalties, counter national unity but also obscure national distinctions of wealth and privilege" 38 .

The life in cities and the employment in modern activities can, of course, function as "melting pot" which wipes out sociocultural differences and liberates the migrants from the compulsion of traditional ties. It cannot, however, be overlooked that connections with family, relatives or friends from the native village and the relationships with ethnic groups possess a considerable importance for the labour migrants and their stay in the modern sector. In many cases this prolongation of traditional ties implies that members of an ethnic group live together in "exile communities" and have headmen who play a role similar to chiefs during their residence in towns. It is not adequate to interpret this merely as a prolongation of traditional relations into the modern sector. The relations are not only adapted to new demands of an urban environment, they also go beyond that: "Tribal" identity emerges even among communities which originally are not organized in complex structures like tribes ${ }^{39}$. The belonging to a distinct ethnic group and the socio-cultural differences between various groups are stressed by the fact that labour migration is regulated by these ethnic relations and that furthers a regional and occupational specialization of various groups ${ }^{40}$. Relations and organizations on an ethnic basis provide the newcomers and temporarily unemployed with a "network of social security". If this mutual hilp is demanded for longer time it becomes gradually a one-way transfer and loses thereby its reciprocal value for the donor. Thus new networks of social relations emerge between long-term unemployed of different ethnic origin: "They are the first significant manifestation... of incipient economic, social and political stratification along class lines"41.

At the lower end of each stratification scheme three groups are supposed to articulate conflicts of interest with positions at the top: Firstly, manual workers in town who live close to the subsistence level are disappointed, particularly by the contrast between their actual situation and their aspirations as they migrated to towns. Secondly, the increasing number of school-leavers and drop-outs from institutions of higher education is frustrated even more, since it cannot approach "elite" and "subelite" positions it aspired for. Thirdly, unemployed city-dwellers who cannot or don't want to return to the countryside form a kind of "sub-

\footnotetext{
37 Cf. Amin, 1971, pp. 89/90; Amin, 1974, p. 109; Joshi et. al., 1975, p. 305; Lloyd, 1972, pp. $268 / 9$. Arrighi's concept of "labour aristocracy" embraces the "elite" and "subelite" as well as semiskilled workers who are employed in the modern sector. The "semiproletarianized peasantry (which increasingly becomes a non-competing group vis a vis the semiskilled proletariat)" (1970, p. 239) is situated at the lower end of this stratification scheme. At least as for Ghana Jeffries (1975) criticizes this scheme, and the implied assumption of antagonism between semiskilled workers and the peasantry.

38 LLOYD, 1972 , p. 269.

39 Cf. Hart, 1971; Skinner, 1965, pp. 76/7.

40 Cf. Hart, 1971, pp. 27, 34; Hart, 1974, pp. 329/30; Hill, 1970; IMF, 1973, p. 261; Joshi et. al., 1975, pp. $296 / 7$.

41 Gutkind, 1973, p. 131.
} 
proletariat"42. One should not underrate the importance of the second group which is easy to mobilize for multifarious political demands. It appears, however, more as a vehicle used by other groups in order to point open conflicts.

We have seen that the organizational strength of trade-unions was impaired by high proportions of labour migrants among the wage earners. Its weakness is furthered through institutional dispersion even when trade-unions have been recognized by the colonial administrations since the 1930's. Therefore, the potential of conflict inherent in wage labour relations is revealed not so much in open actions, but in hidden forms of resistence such as "absenteeism" and high rates of turnover. The organizational strength of trade-unions increases after independence. This must not imply that trade-unions become more efficient to attend to workers' interests. In many cases they are subjected to the political goals of government. Strikes are suppressed, since they seem to sabotage the national task of development. Nevertheless, they remain the most efficient articulation of protest and turn increasingly against the government ${ }^{43}$. The segmentation of the labour market along ethnic lines implies that the prospects to get employed in urban areas and in particular occupations are different for various ethnic groups. Thus the competition among wage-earners and their weak position in the labour market transform themselves into disputes between ethnic groups and particularistic demands on ethnic or regional basis ${ }^{44}$. The potential of conflict inherent in long-term unemployment is revealed by attempts to develop associations of unemployed into political movements for protest. Neither existing voluntary associations organized along ethnic lines, nor trade-unions provide efficient channels to stress the urgency of their demands. For example, trade-unions must be afraid that their bargaining position is impaired by the unemployed ${ }^{45}$. Even manifestations of conflict which intensify ethnic divisions have consequences. The meaning of such "tribalist" forms of revealing conflicts is ambivalent. On the one hand, it undermines the cohesion of the state's organization, and on the other, political leaders and the state's apparatus can use them to play different ethnic groups against each other. Furthermore, a diverting tactic of conflict resolution is to shift potential conflicts to neighbouring African states. In addition this outlet promotes national unity, at least in so far as it raises chauvinist emotions ${ }^{46}$.

Modernization theories of ten presuppose that social change brings about an "achieving society" which provides "vertical mobility" by means of competition between its members. This model is mainly of ideological significance even for "developed" capitalist class societies; much more so for periphery capitalist societies where inequalities of modern and traditional origin are intersecting. The structural heterogeneity relates also to the manifestation of conflicts and their political articulation. Thus another characteristic feature of these societies is that uniform rules for conflict resolution do not emerge.

42 Cf. Gutkind, 1973; Lloyd, 1972, pp. 122, 152, 239, 306/7, 341/2.

43 Cf. Arrighi, 1970, pp. 236-238; Damachi, 1974, especially pp. 125-137; Hopkins, 1973, pp. 257/8, 267-271; Jeffries, 1975, pp. 65-70; Lloyd, 1972, pp. 203/4, 206, 239, 311, 341; Roper, 1958, pp. $38-40,70-78$.

44 Cf. Little, 1974 , pp. 17, 50-52, 89-93; Lloyd, 1972, pp. 110, 115/6, 121, 193-203.

45 Cf. Gutkind, 1973, pp. 131/2. This may subpin the thesis of Arrighi (1970, pp. 256/7).

46 Cf. Little, 1974, pp. 55, 73; Lloyd, 1972, pp. 288-303, 336. Thus the expulsion of labour migrants or small businessmen from neighbouring countries is a popular device of employment policy". Cf., e. g. Adomako-Sarfoh, 1974; Damachi, 1974, p. 93; IMF, 1975, pp. 123-125; Joshi et. al., 1975, pp. 292, 294, 297, 301/2, 306 . 
ADOMAKO-

$\triangle A K F O H, J$.

AMIN, S.

AMIN, S. (ed.)

AMIN, S.

AMSELLE,

J.-L. (ed.)

ARRIGHI, G.

BERG, E. J.

BERG, E. J.

CROWDER, M.

DAMACHI, U. G.

DARKOH, M. B. K.

EWUSI, K

FRANK, C. R.

GODFREY, E. M

GUTKIND, P. C. W.

HART, K.

HART, K.

HILL, P.

HILL, P.

HOPKINS, A. G.

IMF

IMF

JEFFRIES, R.
HABERMEIER, K.

1974: The effects of the expulsion of migrant workers on Ghana's economy, with particular reterence to the cocoa inuustry, in: AMIN, J. (ed.), 1y/4, pp. 13ó- 0

1971: L'Afrique de l'Ouest bloquée. L'économie politique de la colonisation 1880-1970, Paris: Editions de Minuit

1974: Modern migrations in Western Africa. Studies presented and discussed at the 11 th International Atrican jemınar, Lakar, April 1972, London: Oxtord U. P.

1974: Modern migrations in Western Atrica, in: AMIN, S. (ed.), 1974, pp. 65-124

1976: Les migrations africaines, reseaux et processus migratoires, par MI. Aghassian, J.-L. Amselle, M. S. Baldé, M. Hièloux. .., Parıs: Maspero

1970: International corporations, labor aristocracies, and economic development in tropical Africa, in: Rhodes, R. I. (ed.): Imperialism and underdevelopment: a reacier, New York, London: Monthly Review l'ress, pp. 220-267

1961: Backward-sloping labor supply functions in dual economies - the Africa case, in: Quarterly Journal of Economics 7j, pp. 468-492

1965: The economics of the migrant labor system, in: KUPER, H. (ed.), 1965, pp. $160-81$

1968: West Africa under colonial rule, London: Hutchinson

1974: The role of trade unions in the development process. With a case study of Ghana, New York: Praeger

1975: Toward a planned industrial reallocation pattern in Ghana, in: El-Shaks, S./Obudho, R. (eds.): Urbanization, national development, and regional planning in Africa, 2nd print., New York: Praeger, pp. 110-29

1977: Employment performance of Ghanaian manufacturing industries, Geneva: International Labour Office (= Income Distribution and Employment Programme, Working Paper 49)

1968: Urban unemployment and economic growth in Africa, in: Oxford Economic Papers n. s. 20 pp. $250-274$

1973: Economic variables and rural-urban migration: some thoughts on the Todaro hypothesis, in: Journal of Development Studies 10, pp. 66-78.

1973: The unemployed and poor in urban Africa, in: JOLLY, R. ET AL. (eds.), 1973, pp. $124-133$

1977: Bäuerliche Gemeinschaften, kapitalistische Exportwirtschaft und Wanderarbeit in Westafrika. Das Beispiel der Arbeitermigrationen zwischen Volta-Niger-Raum und Südghana, 1900-1970, Karlsruhe: M. Wahl

1971: Migration and tribal identity among the Frafras of Ghana, in: Journal of Asian and African Studies 6, pp. $21-36$

1974: Migration and the opportunity structure: a Ghanaian case-study, in: AMIN, S. (ed.), 1974 , pp. $321-342$

1963: The migrant cocoa farmers of southern Ghana. A study in rural capitalism, Cambridge: Cambridge U. P.

1970: The occupations of migrants in Ghana, Ann Arbor: University of Michigan

1973: An economic history of West Africa, London: Longman

1973: Surveys of African economies, vol. 3..., 2nd print., Washington, D. C.: International Monetary Fund

1975: Surveys of African economies, vol. 6..,, Washington, D. C.: International Monetary Fund

1975: The labour aristocracy? Ghana case study, in: Review of African Political Economy no. 3, pp. 59-70

JOLLY, R. ET AL. (eds.)1973: Third world employment. Problems and strategy. Selected readings, Harmondsworth: Penguin

JOLLY, R. ET AL.

1973: Introduction, in: JOLLY, R. ET AL., (eds.), 1973, pp. 9-27

JOSHI, H. ET AL.

1975: Urban development and employment in Abidjan, in: International Labour Review 111, pp. 289-306

KNIGHT, J. B.

1972: Rural-urban income comparisons and migration in Ghana, in: Bulletin, Oxford University Institute of Economics and Statistics 34, pp. 199-228

1965: Urbanization and migration in West Africa, Berkeley etc.: U. of California P.

1965: Introduction, in KUPER, H. (ed.), 1965, pp. 1-22

1975: Petty producers and capitalism, in: Review of African Political Economy no. 3 , pp. $20-32$ 
LITTLE, K.

LLOYD, P. C.

MARX, K.

MEILLASSOUX, C

N'DOYE, E.

REYNOLDS, L. G.

ROPER, J. I.

SCHMIDT, A.

SENGHAAS, D.

SIEBERT, H.

SKINNER, E. P.

STEWART, F./ STREETEN, P.

TODARO, M. P.

TODARO, M. P.
1974: Urbanization as a social process. An essay on movement and change in contemporary Africa, London: Routlege \& K. P.

1972: Africa in social change, 4th print., Harmondsworth: Penguin

1968: Das Kapital. Kritik der politischen Okonomie, Dritter Band, in: Marx, K./Engels, F.: Werke, ed. by Institut für Marxismus-Leninismus beim ZK der SED, vol. 25, 2nd ed., Berlin: Dietz

1972: Imperialism as a mode of reproduction of labour-power. Paper for the conference on "The significance of the theory of pre-capitalist economic formations for the analysis of peripheric capitalism", Center for Interdisciplinary Research, Bielefeld

1974: Migration des pionniers Mourid wolof vers les terres neuves: rôle de l'économique et du réligieux, in: AMIN, S. (ed.), 1974, pp. $371-383$

1969: Economic development with surplus labour: some complications, in: Oxford Economic Papers n. s. 21, pp. $89-103$

1958: Labour problems in West Africa, London: Penguin

1976: Approaches to the study of conflicts between developed and developing countries, in: Law and State 14, pp. 96-115

1975: Multinational corporations and the third world. On the problem of the further integration of peripheries into the given structure of the international economic system, in: Journal of Peace Research 12, pp. 257-274

1969: Regional economic growth: theory and policy, Scranton, Penn.: International Textbook Company

1965: Labor migration among the Mossi of the Upper Volta, in: KUPER, H. (ed.), 1965 , pp. $60-84$

1971: Conflicts between output and employment objectives in developing countries, in: Oxford Economic Papers n. s. 23, pp. 145-68

1969: A model of labor migration and urban unemployment in less developed countries, in: American Economic Review 59, pp. 138-148

1973: Income expectations, rural-urban migration and employment in Africa, in: JOLLY, R. ET AL. (eds.), 1973, pp. 94-105

WORLD BANK ATLAS 1975: Population, per capita product and growth rates, Washington, D. C. 


\title{
Social Control instead of Social Change: The Administration of Land Reform in the Dominican Republic
}

\author{
By Hans F. Illy
}

It is nearly a commonplace now that land tenure constitutes a significant dimension of the pattern of political power in many countries. Consequently, land reforms should be analysed much more as a political process than as a merely technical one. Or more precisely, the following question has to be answered: Which are the political and social factors that have determined the poor outcome of the reform effort? As the public administration system is the main implementing agency of land reform, an emphasis should be laid on its scope of action in relation to the political actors who set the general policy.

After having given some relevant data on land reform in the Dominican Republic and its origin and orientation through outside pressure in the sixties, the study focusses on the administrative set-up and implementation process of "reforma agraria" going into the details of how far specific laws are put into practice.

The overall picture drawn from this analysis is the following:

1. The reform is extremely slow and has by no means contributed to solve the problems of "minifundios" and landless agricultural labourers.

2. There is a marked discrepancy between offical declarations proffered by President Balaguer and inadequate resources given to the executing agency, the Instituto Agrario Dominicano.

3. The programme has not decisively diminished the concentration of land in the hands of few people. Either large sectors are excluded from the reform (especially the sugar lands) or the "terratenientes" have used their bargaining power to turn the laws into mechanisms to strengthen their position (e.g. via most favourable compensations).

4. The civil service has no proper freedom of action. It is completely subdued to the political will of those in power and is embedded into their value system.

5. The Dominican Republic offers a most traditional example of a political system of the corporative-patrimonial type. Patron-client relationships prevail behind a façade of legalism and constitutionalism. Political issues such as land reform are not allowed to jeopardize vested interests of the ruling groups. The latter are prepared to make certain concessions to absorb social pressure from below but impose strict limits: Land reform becomes more an instrument of social control than of social change.

\section{Labour migration and structural heterogeneity in West Africa}

\section{By Alfred Schmidt}

The interpretation of labour migration as a mechanism which connects different structural elements of capitalist societies at the periphery implies a criticism of some common views: Migration is said to reallocate human resources efficiently, to modernize "backward" subsistence economies, to eliminate regional differences of development, and to indicate social change which brings about an "achieving 
society" and provides "vertical mobility". A few of these questions are discussed in this paper which is based upon studies on West African countries, especially Ghana, Ivory Coast, Senegal, and Upper Volta.

One characteristic of these countries is their low degree of internal and intraregional integration which is combined with their partial integration in the world market. Under these conditions it can be deduced from models of regional economic growth that the result of labour migration is rather a further deepening of unequal development between immigration zones (urban agglomerations, rural export sectors) and emigration zones (mainly subsistence economies).

After labour migration has been established as a self-sustaining process during the colonial period, the changes thereby induced in the subsistence economies swell the stream of migration. After formal decolonization the increasing number of migrants meets modern urban sectors which possess only a limited absorptive capacity due to the bottlenecks of the industrialization by import substitution. Rural-urban income differences which seem responsible for the resulting urban unemployment are, however, not the primary cause of this migration process. As well, the manipulation of a single strategic variable such as urban wage rate cannot be taken as an adequate solution.

The relations of migrants with their home region extend also to the apparent "melting pot" of urban immigration areas. "Traditional" ties of this kind cross "modern" patterns of stratification. Thereby conflicts are manifested in a particularistic, e.g. "tribalist" way which hinders thorough structural changes. All together, labour migration seems to reproduce the existing structure of West African societies and even to deepen its heterogeneity. This applies to the economic as well as to the socio-political level.

\section{Benjamin Constant and the Doctrinaire Liberal Influence in Hispanic America}

\section{By O. Carlos Stoetzer}

Among the Liberal influences of the early nineteenth century, Doctrinaire Liberalism was a most important movement which shaped the Romantic mind of Hispanic America. Benjamin Constant was not strictly speaking linked to the Doctrinaires of Royer-Collard and to the ecclecticism of Cousin, but was nonetheless quite close to them. Both the Doctrinaires and the more independent mind of Constant were aristocratic: they tried to apply the Hegelian synthesis to the eternal problems of liberty and authority, and thus reflected the spirit of the industrial revolution, of the rising bourgeosie and oft the Rechtsstaat. Constant's ideal was constitutional monarchy with the fourth power, equally opposed to the enlightened despotism of the ancien régime, the totalitarian democracy of Rousseau and the French Revolution, and the democratic caesarism of Bonaparte.

Constant shaped the Liberalism of Rivadavia and the Generación de 1837 in the River Plate as well as the conservative governments of Chile (Portales and the Constitution of 1833); he influenced the Imperial Constitution of Brazil with its Poder Moderador, and he had a significant impact on Bolívar (Constitution of 1826). Furthermore, Mexico's conservative Constitution of 1835 with its 